\title{
Confirmation of the recurrent ACVR1 617G $>A$ mutation in South Africans with fibrodysplasia ossificans progressiva
}

\author{
Collet Dandara, Chris Scott, Mike Urban, Karen Fieggen, Regan Arendse, Peter Beighton
}

Objective. Fibrodysplasia ossificans progressiva (FOP) is a rare genetic condition in which progressive ossification of fibrous tissue, tendons and ligaments leads to severe physical handicap. Most affected individuals who have been studied have a recurrent $617 \mathrm{G}>\mathrm{A}$ mutation in the ACVR1/ALK2 gene that codes for activin A type 1 receptor/activin-like kinase 2 . The majority of publications on the genetics of FOP have concerned whites or Asians, and no genetic information is available concerning sub-Saharan blacks. The aim of the project was to determine whether or not this mutation is present in affected persons in South Africa.

Method. Molecular mutational analysis was undertaken on genomic DNA from peripheral blood leukocytes from 6 affected
South Africans of different population groups (4 Xhosa, 1 coloured, 1 white)

Results. The 6 persons with FOP were all heterozygous for the ACVR1/ALK2 617G>A mutation. This mutation was absent in 6 controls.

Conclusion. Confirmation of the presence of this recurrent mutation facilitates diagnostic accuracy in affected persons in South Africa, and allows researchers to narrow the search for molecular targets for rational intervention to the ACVR1/ALK2 domain.

S Afr Med J 2012;102(7):631-633.
Fibrodysplasia ossificans progressiva (FOP) [OMIM 135100] is a rare genetic disorder in which ossification of connective tissue leads to severe disability. It is an autosomal dominant trait and affected persons have mutations in the activin A type 1 receptor gene (ACVR1), chromosomal locus $2 \mathrm{q} 23-24 .{ }^{1}$ ACVR1 is one of the $\mathrm{f} 4$ type 1 receptors that mediate in the highly conserved bone morphogenetic protein (BMP) signalling pathway, through a domain rich in glycine and serine (GS-domain) residues. ${ }^{2,3}$

Diagnosing FOP has depended on recognising characteristic clinical and radiological features, and until recently the causative mechanism remained elusive. ${ }^{2,3}$ FOP molecular investigations has revealed that most affected individuals have the same single nucleotide change $617 \mathrm{G}>\mathrm{A}$ in the $A C V R 1$ gene. The base change is a missense mutation that leads to the substitution of arginine with histidine (R206H). The point mutation $617 \mathrm{G}>\mathrm{A}$ in $A C V R 1$ that occurs in the GS-domain alters the ligand-dependent sensitivity for BMP signalling in connective tissue progenitor cells. Under normal circumstances, type 1 receptors such as ACVR1 are inactive until stimulated by extracellular BMPs through phosphorylation. ${ }^{1-3}$

Division of Human Genetics, Faculty of Health Sciences, University of Cape Town Medical School

Collet Dandara, $\mathrm{PhD}$

Karen Fieggen, MB ChB, FCPaed, Cert Medical Genetics

Peter Beighton, OMB, MD, PhD, FRCP, FRSSA

Department of Paediatrics, Red Cross War Memorial Children's Hospital and University of Cape Town Medical School

Chris Scott, FCPaed (SA)

Division of Molecular Biology and Human Genetics, Faculty of Health Sciences, Stellenbosch University

Mike Urban, FCPSA, Cert Medical Genetics

Division of Rheumatology, University of Cape Town and Groote Schuur Hospital Regan Arendse, PhD, FCPSA
FOP diagnosis is often delayed owing to its rarity. The clinical manifestations may also be confused with those of arthrogryposis multiplex congenita, several genetic rigid-joint syndromes, and various forms of childhood rheumatic disease.

As most genetic analyses have been carried out in white and Asian populations, the question arises as to whether or not this specific mutation $(617 \mathrm{G}>\mathrm{A})$ is associated with FOP in all populations. No sub-Saharan black molecular studies interrogating the genetics of ACVR1/ALK2 and its association with FOP have been reported. Therefore, we investigated whether the commonly reported ACVR1/ $A L K 2$ 617G $>A$ recurrent mutation also causes FOP in indigenous South Africans.

\section{Methods}

Six persons with FOP (4 Xhosa, 1 coloured and 1 white) were available for molecular investigation (Table 1). Three of them were the subject of reports, including full clinical and radiological descriptions, concerning the management and dental implications of FOP in South Africa. ${ }^{4,5}$

The main features of FOP in the affected South Africans were consistent with the literature. The severity and rate of progression are variable. FOP often presents at birth with shortening and deviation of the great toes. General health remains good and early development is normal. In mid-childhood, tender subcutaneous lumps may appear, frequently on the upper region of the back, that become ossified, and widespread ectopic ossification develops in the connective tissues. The limbs, neck and jaw become tethered by bands of ossification resulting in immobility. Finally, movements are limited to the external muscle of the eye and the diaphragm. Death usually occurs by middle age from respiratory insufficiency.

Blood was obtained for molecular genetic analysis from the 6 FOP patients and 6 ethnic-matched controls after obtaining informed consent in accordance with the requirements of the Human Research Ethics Committee, University of Cape Town (ref HREC 026/2010 - PB). Genomic DNA was extracted from peripheral blood leukocytes using a Qiagen DNA extraction kit (Valencia, USA). The single nucleotide polymorphism $617 \mathrm{G}>\mathrm{A}$ in $A C V R 1$ was analysed according to the method of Shore et al. ${ }^{1}$ using PCR and restriction fragment length polymorphism (RFLP) using $H p h I$ and 
Table 1. Main features of the 6 subjects with FOP

\begin{tabular}{|c|c|c|c|c|c|}
\hline Patient & Gender & Year of birth & Ancestry & Disability & Additional comments \\
\hline $\begin{array}{l}\text { FOP } \\
1.1\end{array}$ & $\mathrm{~F}$ & 2005 & Xhosa & $\begin{array}{l}\text { Extensive heterotopic ossification } \\
\text { over back and spine. Arms and neck } \\
\text { immobile and arms tethered to thorax. }\end{array}$ & Legs spared at this point. \\
\hline $\begin{array}{l}\text { FOP } \\
2.1\end{array}$ & M & 1965 & Xhosa & $\begin{array}{l}\text { Spine and arms completely immobile. } \\
\text { Able to walk unaided. }\end{array}$ & $\begin{array}{l}\text { No clinical features of thoracic } \\
\text { insufficiency syndrome. Gainfully } \\
\text { employed. }\end{array}$ \\
\hline $\begin{array}{l}\text { FOP } \\
3.1\end{array}$ & $\mathrm{~F}$ & 1964 & Xhosa & $\begin{array}{l}\text { Completely immobile. Only able to } \\
\text { move eyes and tongue. }\end{array}$ & $\begin{array}{l}\text { Profound iron deficiency anaemia } \\
\text { owing to diet of tea and bread as } \\
\text { unable to open mouth and chew. } \\
\text { Thoracic insufficiency syndrome and } \\
\text { pulmonary hypertension. }\end{array}$ \\
\hline $\begin{array}{l}\text { FOP } \\
4.1\end{array}$ & $\mathrm{~F}$ & 2003 & Coloured & $\begin{array}{l}\text { Heterotopic ossification over back and } \\
\text { spine. Arms and neck immobile and } \\
\text { arms tethered to thorax. }\end{array}$ & $\begin{array}{l}\text { Presented after injury at school. Has } \\
\text { had serious fall owing to inability to } \\
\text { protect with arms and developed large } \\
\text { swelling over right eye. }\end{array}$ \\
\hline $\begin{array}{l}\text { FOP } \\
5.1\end{array}$ & $\mathrm{~F}$ & 2009 & Xhosa & $\begin{array}{l}\text { Hard mass between scapulae. Rigid } \\
\text { cervical spine and limited abduction of } \\
\text { arms. }\end{array}$ & $\begin{array}{l}\text { Fitted with a helmet to protect against } \\
\text { head injuries. }\end{array}$ \\
\hline $\begin{array}{l}\text { FOP } \\
6.1\end{array}$ & $\mathrm{~F}$ & 1997 & White & $\begin{array}{l}\text { Spinal immobility noted only months } \\
\text { before diagnosis. }\end{array}$ & $\begin{array}{l}\text { Had surgical correction of toes at } 5 \\
\text { months of age. }\end{array}$ \\
\hline
\end{tabular}

Cac8I. The $617 \mathrm{G}>\mathrm{A}$ mutation in ACVR1 eliminates a Cac $8 I$ site and forms a new HphI site (Fig. 1). In addition, each of the samples was subjected to sequence analysis.

\section{Results}

The 350 bp PCR product from the normal allele $(617 \mathrm{G})$ after digestion with $\mathrm{Cac} 8 \mathrm{I}$ showed the 3 bands $(139,114$, and 97 bp) while the mutant allele (617A) appeared as 2 bands (253 and $97 \mathrm{bp)}$ in persons with FOP. For HphI, PCR products of the $617 \mathrm{G}$ allele (normal) were not digested but PCR products of the 617A allele showed bands of 228 and $122 \mathrm{bp}$ in the FOP patients. All 6 persons with FOP were heterozygous for the $617 \mathrm{G}>\mathrm{A}$ mutation. The mutation was absent in all 6 controls. Sequence analysis (Fig. 2) revealed the heterozygous genotype in all affected individuals while the controls had the normal homozygous $617 \mathrm{G} / \mathrm{G}$ genotype.

\section{Discussion}

Most individuals with FOP are sporadic, representing new mutations for the determinant gene. Although FOP has a worldwide distribution, there are few previous reports of affected persons in South Africa. ${ }^{6}$ Four of the 6 persons investigated in Cape Town are Xhosa. Reports from several other parts of the world have confirmed the presence of the $617 \mathrm{G}>\mathrm{A}$ specific mutation in persons with FOP. However,

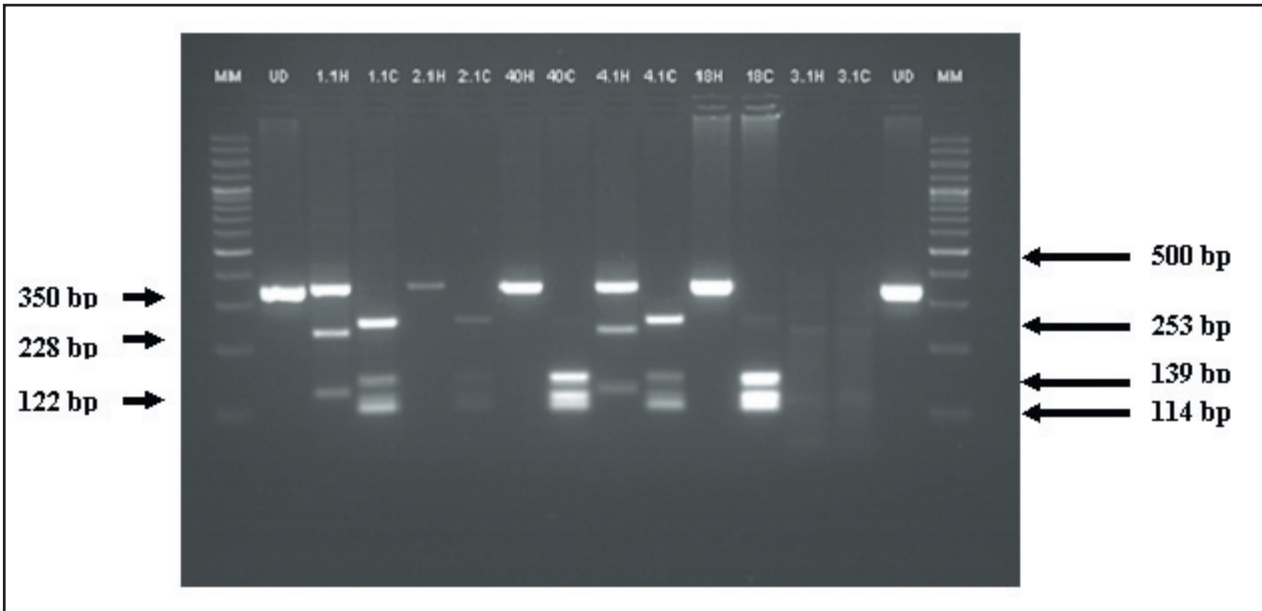

Fig. 1. Mutation analysis of the ACVR1 in South African FOP patients. Patient samples were numbered 1.1; 2.1; 3.1 and 4.1, respectively. UD represents undigested $350 \mathrm{bp}$ PCR product while MM is the molecular weight marker. Samples 18 and 40 are healthy controls with no clinical manifestation of the disease. Each sample was digested with Hph I and Cac8 I in separate reactions and each reaction identified with either $\mathrm{H}$ for $\mathrm{Hph}$ I or C for Cac8 I respectively. The products for the separate digestions for each enzyme were run alongside each other, for example, $1.1 \mathrm{H}$ and 1.1C, respectively. After Hph I digestion of the $350 \mathrm{bp}$ PCR product, the $617 \mathrm{G}$ allele (normal) was not digested but PCR products of the 617A allele showed bands of 228 and $122 \mathrm{bp}$ in the FOP patients only. The $350 \mathrm{bp}$ PCR product from the normal allele $(617 \mathrm{G})$ after digestion with Cac8 I showed the three bands (139, 114, and $97 \mathrm{bp}$ ) while the mutant allele (617A) appeared as two bands (253 and $97 \mathrm{bp}$ ) in FOP patients.

the concept of 1 specific mutation in ACVR1 is no longer tenable as evidenced by the reports associating $605 \mathrm{G}>\mathrm{T}, 983 \mathrm{G}>\mathrm{A}, 774 \mathrm{G}>\mathrm{C}$ and $1067 \mathrm{G}>\mathrm{A}$ with FOP in the absence of the recurrent $617 \mathrm{G}>\mathrm{A} .{ }^{2,7}$ Nevertheless, the important feature of these mutations is that their resulting amino acid changes mostly occur in the GS or kinase coding domains. ${ }^{7}$ This observation makes molecular sense in that different mutations in the ACVR1/ALK2 receptor gene could lead to different clinical manifestations of FOP. By extrapolation, mutations within the ACVR1/ALK2 receptor gene that cause variable ACVR1/ ALK2 receptor activity could also lead to different phenotypes, depending on the sensitivities of the domains in which they occur. ${ }^{2,7}$ 


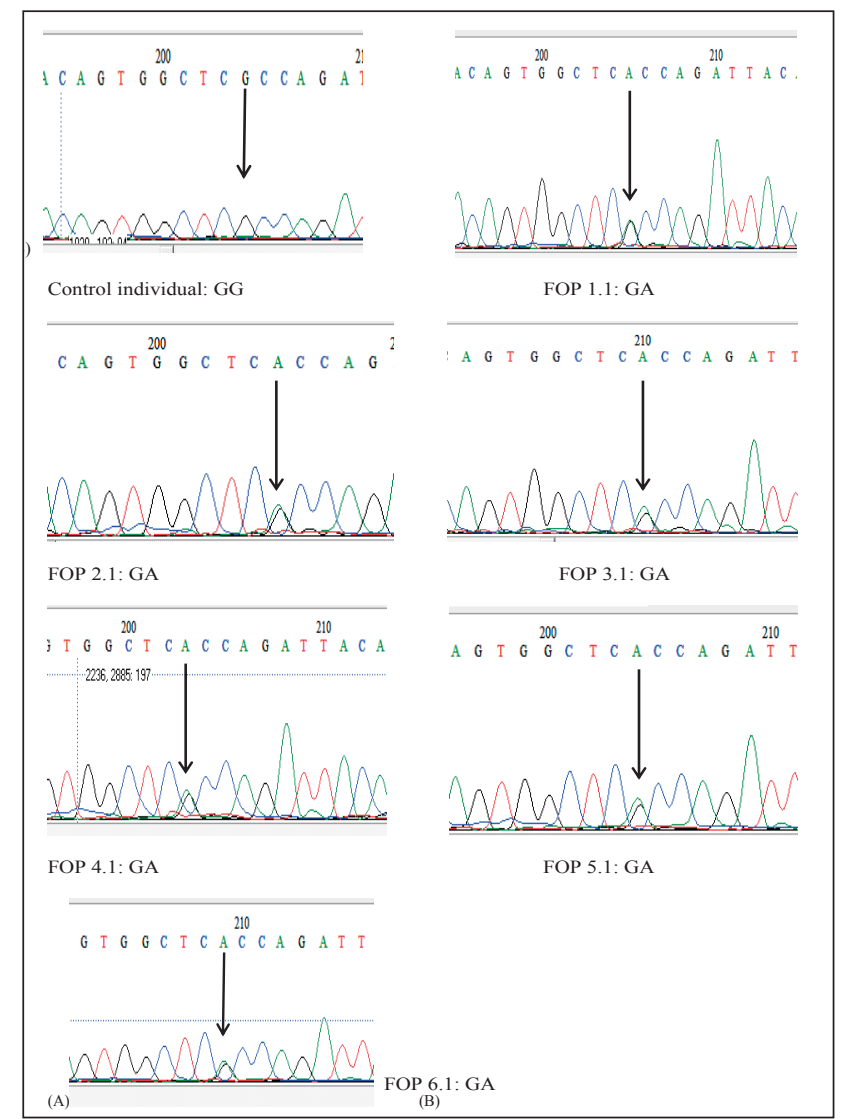

Fig. 2. DNA sequence analysis of a section of the ACVR1/ALK2 gene in South African FOP patients. The arrow indicates position of the gene where the mutation has been reported (c.617G $>A ; R 206 H$ ). The numbering FOP1.1 to FOP6 refers to the different patients with GA representing the heterozygous genotype at this position.

This concept could also argue for the involvement of mutations in ACVR1 receptor gene in other related disorders such as some forms of myositis. ${ }^{2,7}$

The identification of the recurrent $617 \mathrm{G}>\mathrm{A}$ mutation in almost all FOP patients worldwide, together with the narrowing of all reported mutations to the GS and kinase domains of the ACVR1/
ALK2 gene, provides a specific target of intervention in a critical signalling pathway. The prime target in FOP would be inhibition of the BMP signalling pathway, using RNA technology or monoclonal antibodies. ${ }^{1,8}$ In South Africa, confirming the recurrent $617 \mathrm{G}>\mathrm{A}$ mutation in all 6 patients suggests that genetic analysis can aid the diagnosis of suspected FOP, thereby negating the need for invasive procedures that can accelerate its progression.

\section{Conclusions}

Demonstrating that 6 affected South Africans with disparate antecedents have the same worldwide documented $617 \mathrm{G}>$ A mutation provides a firm starting point for establishing a diagnostic molecular testing facility for FOP in sub-Saharan Africa. In turn, awareness of FOP and the feasibility of molecular diagnostic confirmation would positively influence its medical management in Africa. The ubiquity of the $617 \mathrm{G}>\mathrm{A}$ mutation could also facilitate research on identifying molecular intervention strategies that may be applied in FOP patients to slow the progression of the disorder, particularly by targeting the BMP signalling pathway.

Acknowledgements. Collet Dandara and Peter Beighton are grateful to the National Research Foundation (NRF) and the Medical Research Council (MRC) of South Africa for support. Collet Dandara thanks the Research Council of the University of Cape for research support.

\section{References}

1. Shore EM, Xu M, Feldman GJ, et al. A recurrent mutation in the BMP type I receptor ACVR1 causes inherited and sporadic fibrodysplasia ossificans progressiva. Nature Genetics 2006;38:525-527.

2. Kaplan FS, Xu M, Seemann P, et al. Classic and atypical fibrodysplasia ossificans progressiva (FOP) phenotypes are caused by mutations in the bone morphogenetic protein (BMP) type I receptor ACVR1. Hum Mutat 2009a;30:379-390.

3. Kaplan FS, Pignolo RJ, Shore EM. The FOP metamorphogene encodes a novel type I receptor that dysregulates BMP signalling. Cytokine \& Growth Factor Reviews 2009b;20:399-407.

4. Scott C, Urban M, Arendse R, Dandara C, Beighton P. Fibrodysplasia ossificans progressiva in South Africa: difficulties in management in a developing country. J Clin Rheumatol 2011;17:38-41.

5. Roberts T, Stephen LXG, Scott C, Urban M, Sudi S, Beighton P. Fibrodysplasia ossificans progressive (FOP) in South Africa: dental implications in 5 cases. Oral Surg Oral Med Oral Pathol Oral Radiol Endod 2011;112:11-18.

6. Connor JM, Beighton P. Fibrodysplasia ossificans progressiva in South Africa: case reports. S Afr Med 6. Connor JM, Beighto
J 1982;61:404-406.

7. Gregson CL, Hollingworth P, Williams M, et al. A novel ACVR1 mutation in the glycine/serine-rich
19804-406. Gregson CL, Hollingworth P, Williams M, et al. A novel ACVR1 mutation in the glycine/serine-rich
domain found in the most benign case of a fibrodysplasia ossificans progressiva variant reported to date. Bone 2011;48:654-658.

8. Yu PB, Deng DY, Lai CS, et al. BMP type I receptor inhibition reduces heterotopic ossification. Nature Medicine 2008;14:1363-1369.

Accepted 16 January 2012. 